\title{
Karyotypic Characteristics and Genetic Relationships of Apricot Accessions from Different Ecological Groups
}

\author{
Wenwen Li, Liqiang Liu, Weiquan Zhou, Yanan Wang, and Xiang Ding \\ College of Horticulture and Forestry, Xinjiang Agricultural University, Urumqi, Xinjiang 830052 , \\ China
}

\author{
Guoquan Fan and Shikui Zhang \\ Luntai National Fruit Germplasm Resources Garden of Xinjiang Academy of Agricultural Sciences, \\ Luntai, Xinjiang 841600, China
}

\author{
Kang Liao \\ College of Horticulture and Forestry, Xinjiang Agricultural University, Urumqi, Xinjiang 830052, \\ China
}

\begin{abstract}
AdDitional INDEX wORDs. chromosome number, diversity, karyotype analysis, $P$. armeniaca
Abstract. The present study aims to reveal the karyotypic characteristics and genetic relationships of apricot (Prunus armeniaca L.) accessions from different ecological groups. Fourteen, 9, and 30 accessions from the Central Asian ecological group, North China ecological group, and Dzhungar-Ili ecological group, respectively, were analyzed according to the conventional pressing plate method. The results showed that all the apricot accessions from the different ecological groups were diploid $(2 n=2 x=16)$. The total haploid length of the chromosome set of the selected accessions ranged from 8.11 to $12.75 \mu \mathrm{m}$, which was a small chromosome, and no satellite chromosomes were detected. All accessions had different numbers of median-centromere chromosomes or sub-median-centromere chromosomes. The karyotypes of the selected accessions were classified as $1 \mathrm{~A}$ or $2 \mathrm{~A}$. Principal component analysis revealed that the long-arm/short-arm ratio $(0.968)$ and the karyotype symmetry index $(-0.979)$ were the most valuable parameters, and cluster analysis revealed that the accessions from the Central Asian ecological group and Dzhungar-Ili ecological group clustered together. In terms of karyotypic characteristics, the accessions from the Dzhungar-Ili ecological group and Central Asian ecological group were closely related.
\end{abstract}

Fruits are plant-derived products that can be consumed in their raw form without undergoing processing or conversion. Several fruit groups, including temperate, tropical, and subtropical, are adding value to the earth's diversity and are fundamental to all life. They include high contents of nonnutritive, nutritive, and bioactive compounds (Gecer et al., 2020; Senica et al., 2019; Serçe et al., 2010). Apricot ( $P$. armeniaca), which belongs to the Rosaceae family, is cultivated worldwide (Jiang et al., 2019). According to different taxonomic systems, there are six Prunus L. species that are recognized by most scholars: P. armeniaca, Prunus sibirica L., Prunus mandshurica (Maxim.) Skv., Prunus holosericea (Batal.) Kost., Prunus mume Sieb. et Zucc., and Prunus brigantina Vill. (Bortiri et al., 2001). Nearly all cultivated apricot accessions originated from $P$. armeniaca (Zhebentyayeva et al., 2003). On the basis of their geographical distribution characteristics, apricot plants across the world,

Received for publication 11 June 2020. Accepted for publication 29 Oct. 2020. Published online 8 December 2020

This work was supported by the National Key Research and Development Program (grant no. 2016YFC0501504), the Xinjiang Uygur Autonomous Region Horticulture Key Discipline Fund (grant no. 2016-10758-3), and the Xinjiang Agricultural University Crop science postdoctoral research station. We thank American Journal Experts for editorial assistance with the English. K.L. is the corresponding author. E-mail: lioakang01@163.com.

This is an open access article distributed under the CC BY-NC-ND license (https://creativecommons.org/licenses/by-nc-nd/4.0/). including wild species, and cultivated species, were divided into six ecological groups by Chinese scholars (Zhang and Zhang, 2003), namely, Central Asian ecological group (CAG), Dzhungar-Ili ecological group (DZG), North China ecological group (NCG), European ecological group (EG), Northeast Asian ecological group, and East China ecological group. The apricot accessions in these groups displayed extensive morphological and physiological differences as well as extensive adaptability to different ecological zones (Zhang and Liu, 2018).

The Kashgar, Hotan, and Kuqa oasis areas around the Tarim Basin in the southern part of the Xinjiang Uygur Autonomous Region, China, are the main areas of apricot production and contain the greatest abundance of apricot cultivars. The wild apricot forest in Ili, Xinjiang, China, is a relic of broad-leaved forests from the late Tertiary and played a decisive role in the domestication and cultivation of apricot trees worldwide (Zhebentyayeva et al., 2003). This forest is an important part of the deciduous broad-leaved forest below the montane coniferous forest and above the montane grasslands in Xinjiang (Zhang and Zhang, 2003). Only one mountain separates the southern Xinjiang and Ili areas in the northern Tianshan Mountains, and there are several corridors between the northern and southern Tianshan Mountains. Geographically, cultivated apricot trees in the southern Tianshan Mountains of Xinjiang (CAG) most likely evolved from the spread of wild apricot trees in the Ili Valley (DZG). Information on differences in 
chromosome number and karyotypic characteristics between wild and cultivated species can be used as an important tool in fruit tree heredity and breeding (Kazem et al., 2010). Furthermore, wild species can provide an abundance of germplasm resources for improved breeding selections or lines (Kazem et al., 2010).

Variations in chromosome number and karyotypic characteristics are the main mechanisms governing species diversification (Martin et al., 2015). The chromosome number is an important feature in plant cell taxonomy and can provide information about polyploidy and other important genomic changes (Jang et al., 2013). In addition to the chromosome number, the chromosome morphology is often used in plant classification (Martin et al., 2015). Karyotypic analysis can be used to understand relationships among species, processes leading to evolutionary diversification, and the direction of evolution. Chromosomal changes play an important role in plant evolution, diversification, and speciation (Jang et al., 2013). These data can also help to elucidate the origin, morphology and phylogenetic relationships among plant genotypes (Alberto et al., 2003).

A number of cytological studies during the past few decades have provided essential characteristics for phylogenetic and evolutionary analyses (Stace, 2000). However, the number of chromosomes is known for only $\approx 25 \%$ of all angiosperms (Baltisberger and Widmer, 2009). According to the Chromosome Counts Database (Rice et al., 2015), the chromosome number of $P$. armeniaca is 16 . Since the 20th century, the chromosomal characteristics of apricots have aroused the interest of scholars (Lin et al., 1999; Lv, 1986; Wang et al., 1992; Wei and Tang, 1996). Early studies focused on the total number of chromosomes rather than the individual morphology or genetic significance of species revealed by their karyotype parameters. Lv (1986) used the conventional method to determine that the chromosome number of $P$. armeniaca and $P$. sibirica, both of which have small chromosomes, was 16 chromosomes. By using the conventional method, Wang et al. (1992) determined the karyotype formula for $P$. sibirica: $2 n=2 x=16=10 \mathrm{~m}+6 \mathrm{sm}$. Using the hypotonic wall degradation method, Lin et al. (1999) reported that $P$. sibirica, $P$. holosericea, and $P$. mandshurica were diploid. Wei and Tang (1996) used the conventional method to obtain the $P$. armeniaca karyotype formula, $2 n=2 x=16$, and the karyotypes revealed a median-centromere chromosome $(\mathrm{m})$ and sub-median-centromere chromosome $(\mathrm{sm})$. The length of individual chromosomes ranged from 1.43 to $4.9 \mu \mathrm{m}$, with chromosomes belonging to the $2 \mathrm{~A}$ or $2 \mathrm{~B}$ category. To date, information on the karyotypic characteristics and evolution of $P$. armeniaca has been limited. Although there have been some studies on the chromosome number of $P$. armeniaca, there have been no such reports on wild apricot genotypes in Ili, Xinjiang.

In this study, we analyzed $P$. armeniaca accessions from different ecological groups from a cytological perspective to 1) determine their chromosome number and karyotypic characteristics and 2) reveal the genetic relationships among the $P$. armeniaca accessions from different ecological groups. The results of this study will provide a theoretical reference for research on the evolution and breeding of apricot.

\section{Materials and Methods}

Plant materials. Seeds of $53 P$. armeniaca accessions that encompassed three ecological groups, namely, the CAG (cultivated accessions), NCG (cultivated accessions), and DZG (wild accessions), were collected. The seeds of 23 of the cultivated accessions were provided by the Luntai National Fruit Germplasm Resources Garden of the Xinjiang Academy of Agricultural Sciences. The seeds of 30 wild accessions were collected from the natural distribution areas of wild fruit forests within Xinyuan County, Yining County, and Huocheng County (Xinjiang, China) (Fig. 1, Supplemental Table 1).

Chromosome count. The chromosomes of metaphase cells were counted according to the conventional pressing plate method. Chromosome preparation was improved by adopting the methods of Sun et al. (2015) and Chen et al. (2013). The endocarp was removed from each collected seed, after which the seed was soaked in $150 \mathrm{mg} \cdot \mathrm{L}^{-1}$ gibberellic acid $\left(\mathrm{GA}_{3}\right)$ for 24 $\mathrm{h}$ followed by distilled water for $12 \mathrm{~h}$. Root tips were cultured on moist filter paper in a petri dish, after which they were cut to 1.0 to $1.5 \mathrm{~cm}$ in preparation for treatments. The root tips were subsequently cut to $0.5 \mathrm{~cm}$ between 0900 and $1000 \mathrm{HR}$. At $4{ }^{\circ} \mathrm{C}$, the root samples were pretreated in $0.29 \mathrm{~g} \cdot \mathrm{L}^{-1} 8$-hydroxyquinoline solution for $6 \mathrm{~h}$ and then fixed in fixation solution ( 3 methyl alcohol: 1 acetic acid) for $24 \mathrm{~h}$. The fixed root tips were rinsed twice with $95 \%$ ethanol and then stored in $70 \%$ ethanol at $4{ }^{\circ} \mathrm{C}$ for subsequent use. The root tips were acidified in an $83 \mathrm{~mL} \cdot \mathrm{L}^{-1}$ hydrochloric acid solution (36\% to $38 \%$ ) at $60{ }^{\circ} \mathrm{C}$ for $15 \mathrm{~min}$, after which they were immersed in distilled water (hypotonic conditions) at room temperature for $30 \mathrm{~min}$. Last, the root trips were placed on slides and stained with carbol fuchsin (SigmaAldrich, St Louis, MO) for $45 \mathrm{~min}$. The slides were observed under $\times 100$ objectives of the microscope (Eclipse $80 \mathrm{i}$; Nikon, Tokyo, Japan) and then imaged, and the chromosomes were counted with NIS-Elements F 3.0 software (NIS-Elements F 3.0, Nikon).

Calculation of Karyotype parameters. A total of 15 independent karyotype parameters were determined according to their own formula. These karyotype parameters included the following: Stebbins' karyotype [SK (Stebbins, 1971)], mean long-arm/short-arm ratio [MAR (Zhang et al., 2015)], intrachromosomal asymmetry index [A $\mathrm{A}_{1}$ (Romero Zarco, 1986)], interchromosomal asymmetry index $\left[\mathrm{A}_{2}\right.$ (Romero Zarco, 1986)], degree of karyotype asymmetry [A (Watanabe et al., 1999)], dispersion index [DI (Lavania and Srivastava, 1992)], karyotype asymmetry index [AI (Paszko, 2006)], karyotype asymmetry index [AsK\% (Arano, 1963)], karyotype symmetry index [Syi (Greilhuber and Speta, 1976)], chromosomal size resemblance index [Rec (Greilhuber and Speta, 1976)], total form percentage [TF\% (Huziwara, 1962)], total haploid (monoploid) length of the chromosome set [THL (Altınordu et al., 2016)], coefficient of variation of the chromosome length $\left[\mathrm{CV}_{\mathrm{CL}}\right.$ (Paszko, 2006)], coefficient of variation of the centromeric index $\left[\mathrm{CV}_{\mathrm{CI}}\right.$ (Paszko, 2006)], and mean centromeric asymmetry $\left[\mathrm{M}_{\mathrm{CA}}\right.$ (Peruzzi and Eroglu, 2013)].

Karyotyping was performed with KaryoType software (Altınordu et al., 2016). The karyotypes were described in accordance with the methods of Stebbins (1971). Each accession measured at least 30 well-spread metaphase cells. A graphics editor (Adobe Photoshop CS5; Adobe Systems, San Jose, CA) was used for chromosome pairing.

DAta AnAlysis. A cluster analysis (Ghosh et al., 2018) including 15 numerical karyological parameters was conducted to standardize the data matrix and generate an unweighted pair group method with arithmetic mean (UPGMA) dendrogram based on the average euclidean distance via statistical software (IBM SPSS Statistics version 19.0; IBM, Armonk, NY). 


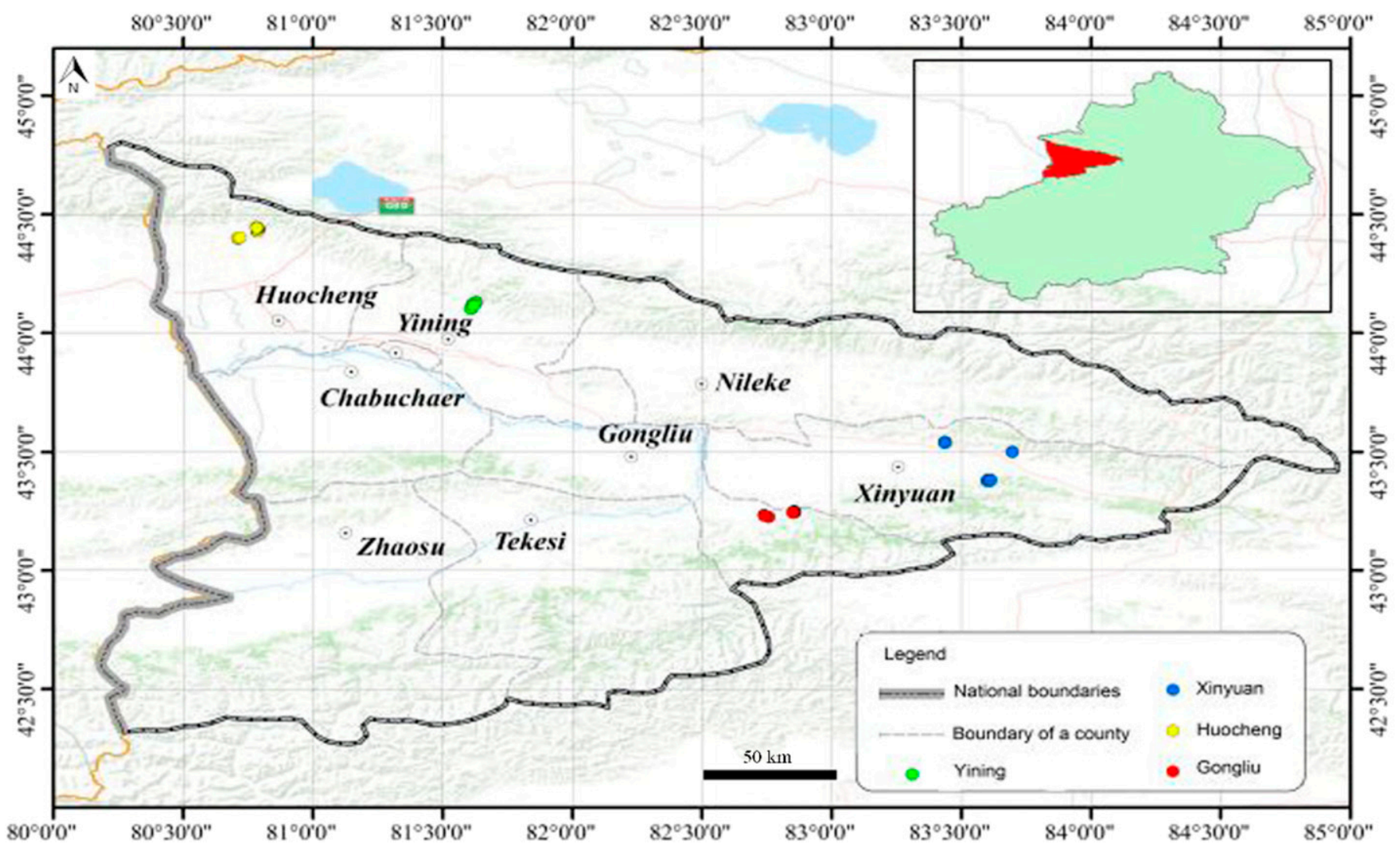

Fig. 1. Geographical distribution of wild Prunus armeniaca.
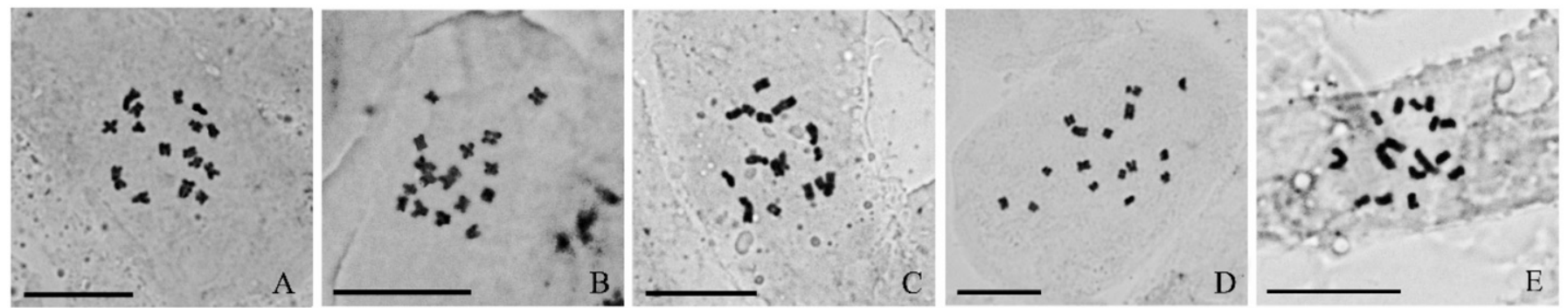

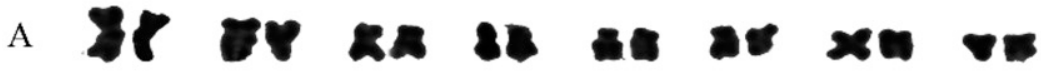

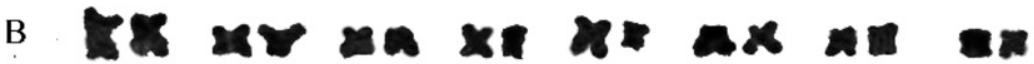

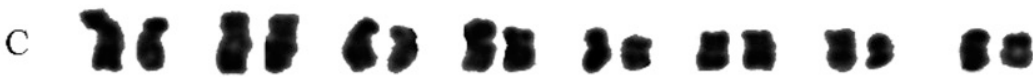

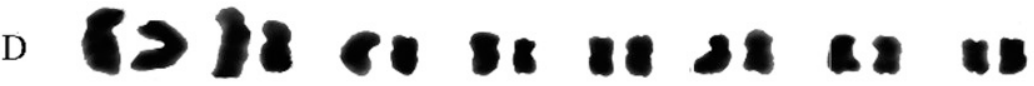

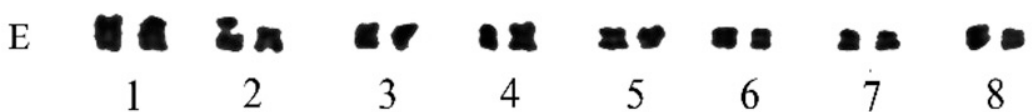

Fig. 2. Micrographs and karyotype of the metaphase of cell division of Prunus armeniaca: (A) DZG 07 accession, (B) DZG 30 accession, (C) DZG 35 accession, (D)

CAG 10 accession, and $(\mathbf{E})$ NCG 04 accession (scale bars $=10 \mu \mathrm{m}$ ). DZG $=$ Dzhungar-Ili ecological group, CAG $=$ Central Asian ecological group, $\mathrm{NCG}=$ North

China ecological group. 


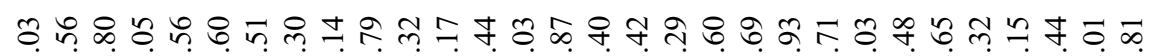

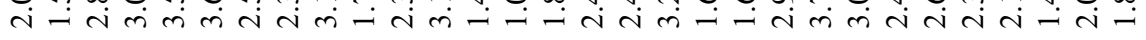
구응 m

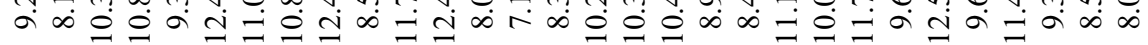

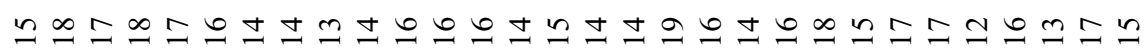

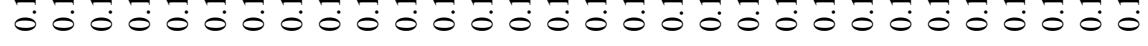

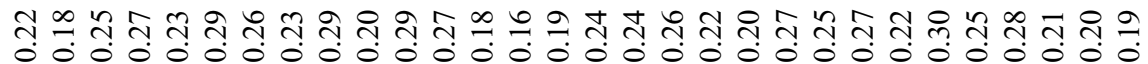

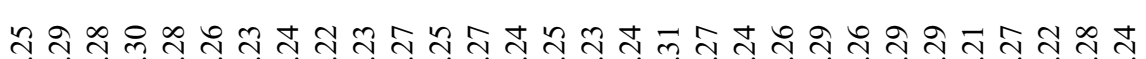

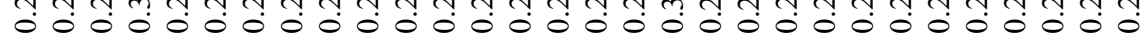

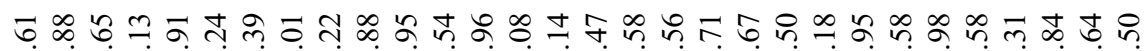
Бे

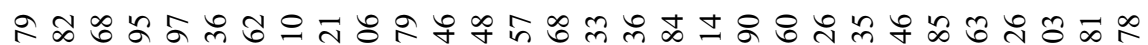

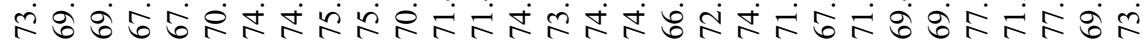

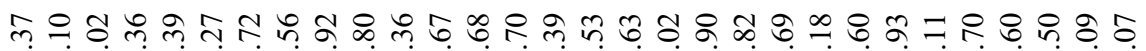

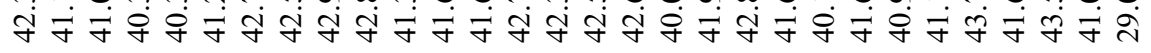

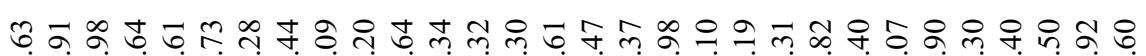

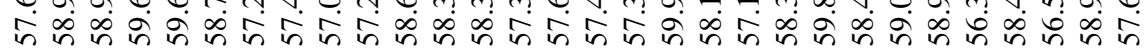

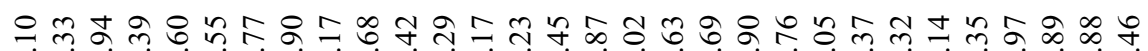

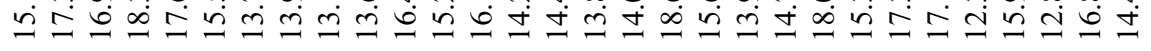
두궁ำ

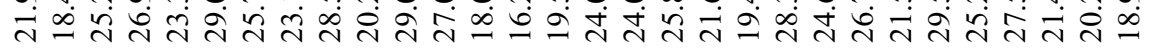

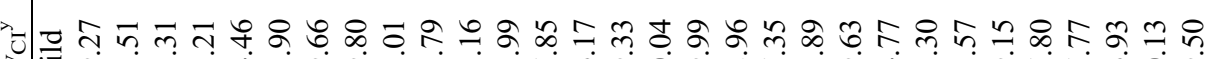
क人

ำ

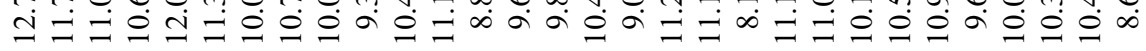

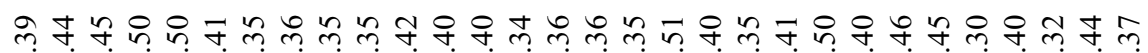

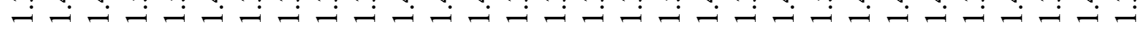

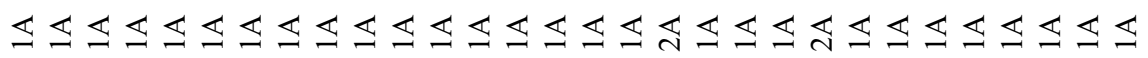

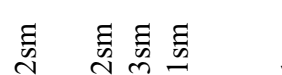

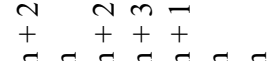

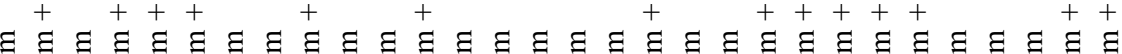

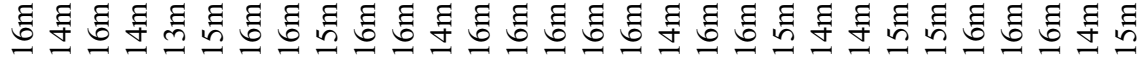
|| || || || || || || || || || || || || | | | | | | || || || ||

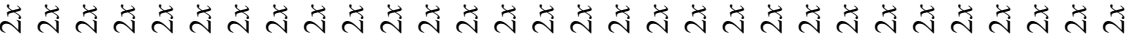

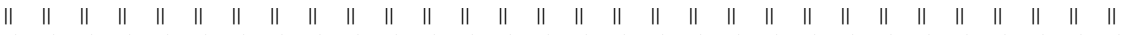

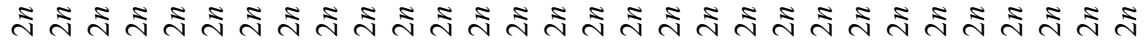

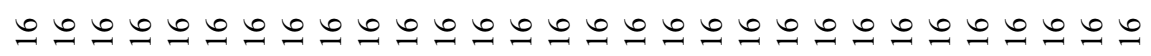

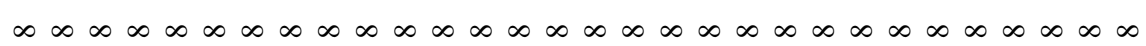

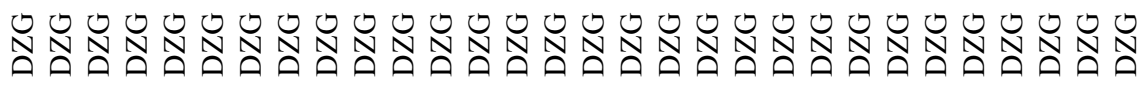

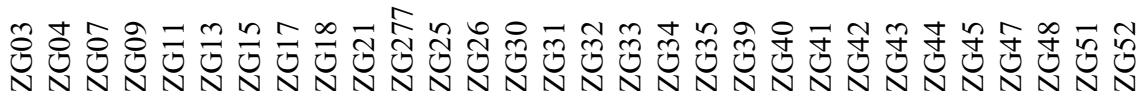

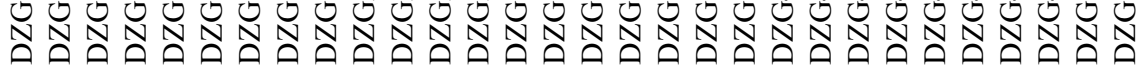

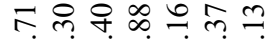
iviricicis 우 $\circ \therefore \circ \sigma \infty \infty$

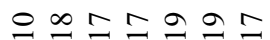
0000000 กิ่

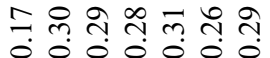
ఈํํำ तु तु่

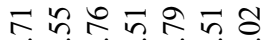
के वें

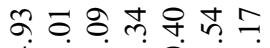
字子户狩子户

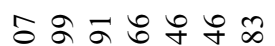

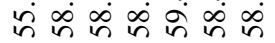

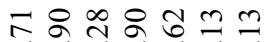
도드응

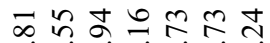
ส่ปั่ ปี่

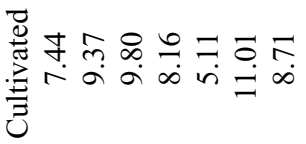

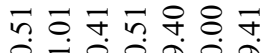

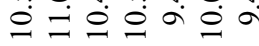

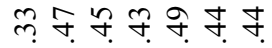

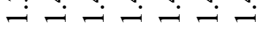

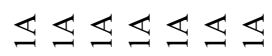
$\begin{array}{lll}\text { ह } & \text { : } \\ + & + \\ + & +\end{array}$

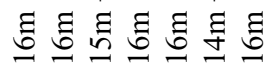
" $\|$ || ॥ |

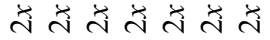
\| \| \| \| \| \| $\|$

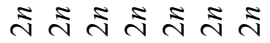
우으으으으응 $\infty \infty \infty \infty \infty \infty \infty$

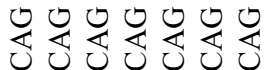

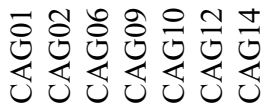




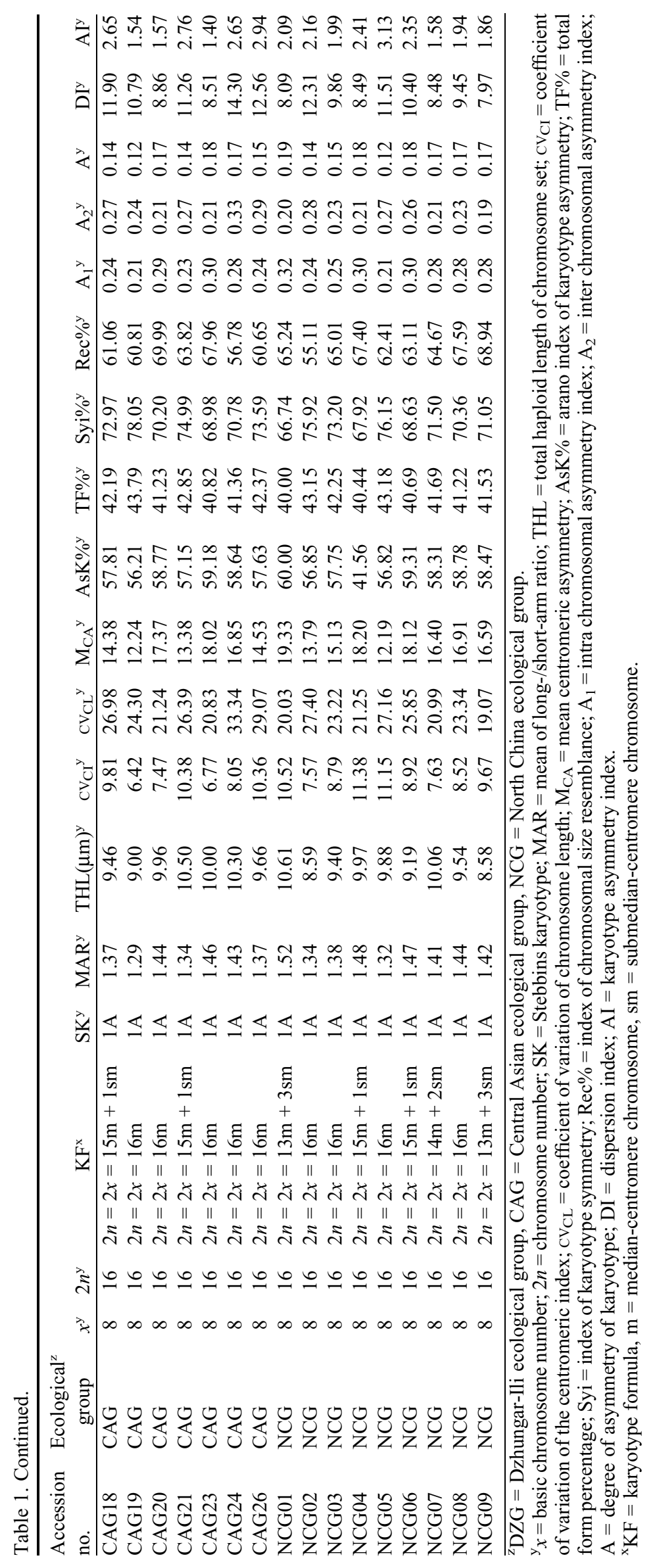


Principal component analysis (PCA) (Anderson, 1963) was performed using IBM SPSS Statistics (version 19.0) to analyze the contribution rate of each karyotype parameter.

In addition, to verify the reliability of the karyotype parameters for the dendrograms, we collected partial data from the studies by Lin (2001) and Wang et al. (1992), including the karyotype parameters of $P$. mandshurica (Lin, 2001), $P$. holosericea (Lin, 2001), P. sibirica (Wang et al., 1992), Prunus cerasifera Ehrh. (Wang et al., 1992), and Prunus spinosa L. (Wang et al., 1992). We combined karyotypic data from $P$. armeniaca and its related species to construct a dendrogram.

\section{Results}

KARYOTYPIC ANALYSIS. Due to the use of the improved method proposed by Sun et al. (2015) and Chen et al. (2013), plates of well-spread metaphase cells with prominent constrictions were visualized over a clear background (Fig. 2). The somatic chromosome number and karyotype formula are shown in Table 1. The different cultivars and individuals presented high intraspecific consistency. The somatic chromosome number of $P$. armeniaca in the CAG, NCG, and DZG accessions was $2 n=2 x=16$ (Table 1, Figs. 2 and 3). The THL of the selected accessions ranged from 8.11 to $12.75 \mu \mathrm{m}$, and the MAR ranged from 1.29 to 1.52 . No satellite chromosomes were detected (Fig. 2).

In total, two types of chromosomes were identified: $m$ and sm. All selected accessions had $\mathrm{m}$, and 23 accessions had both $\mathrm{m}$ and sm (Table 1). According to Stebbins' classification, most of the karyotypes of the selected accessions were classified as $1 \mathrm{~A}$, with the exception of two accessions from the Xinyuan population in DZG, which were classified as $2 \mathrm{~A}$.

In terms of karyotype asymmetry parameters (Table 1), the MAR, $\mathrm{M}_{\mathrm{CA}}, \mathrm{A}_{1}$, and $\mathrm{A}$ exhibited the same trend: the $\mathrm{NCG}$ accession values were the greatest $(1.42,16.29,0.27$, and 0.16 , respectively), and the DZG accession values were the lowest (1.40, 15.44, 0.26, and 0.15, respectively). Among the accessions, the DZG accessions had the greatest values of the $\mathrm{CV}_{\mathrm{CI}}$, AsK $\%$, and AI $(10.49,58.19 \%$, and 2.56, respectively), the NCG accessions had the lowest values of the AsK\% and AI (56.43\% and 2.17, respectively), and the CAG accessions had the lowest $\mathrm{CV}_{\mathrm{CI}}$ (8.49). Moreover, the CAG accessions had the greatest values of the $\mathrm{CV}_{\mathrm{CL}}, \mathrm{TF} \%, \mathrm{~A}_{2}$, and DI $(24.81,41.86 \%$, 0.25 , and 10.54 , respectively), the NCG accessions had the lowest values of the $\mathrm{CV}_{\mathrm{CL}}, \mathrm{A}_{2}$, and DI, and the DZG accessions had the minimum lowest $\mathrm{TF} \%$.
Both the Syi and Rec index revealed karyotype symmetry, with slightly different trends between them. Among the accessions, the DZG accessions had the greatest Syi and Rec index values (72.03\% and $65.31 \%$, respectively), the NCG accessions had the lowest Syi value (71.27\%), and the CAG accessions had the lowest Rec index value (63.95\%).

Cluster analysis. We combined karyotypic data from $P$. armeniaca and its related species to construct a dendrogram (Fig. 4). When the distance coefficient is 10, the species can be divided into four groups. The first group contained $P$. armeniaca and $P$. sibirica. $P$. armeniaca included DZG, CAG, and NCG accessions, among which the DZG and CAG accessions grouped together. $P$. sibirica is located in northeastern China and is very hardy because of its strong adaptability to very cold regions (Zhang and Zhang, 2003). The second group contained $P$. mandshurica, which produces large fruit and is highly cold tolerant (Zhang and Zhang, 2003). The third group contained $P$. cerasifera and $P$. spinosa, and the fourth group contained $P$. holosericea, which produces small fruit and is highly drought and cold resistant (Zhang and Zhang, 2003). Our results were consistent with those of the morphological classification of members of the Prunus genus. From a cytological perspective, karyotype parameters can be used to distinguish Prunus species. With respect to their karyotypic characteristics, $P$. armeniaca and $P$. sibirica were closely related, and the CAG accessions were more closely related to the DZG accessions than to the other accessions.

We analyzed the distribution of wild apricot accessions in Ili and further explored the genetic relationship between populations via UPGMA (Fig. 5). When the distance coefficient was five, the three populations could be divided into two groups. The first group contained Yining County and Xinyuan County apricot accessions, and the second group contained Huocheng County apricot accessions. Geographically, Yining County and Xinyuan County are relatively close to each other, and Huocheng County is relatively far from Yining County and Xinyuan County. Based on the geographical origin, the Yining and Xinyuan populations were grouped together.

Principal Component anAlysis. The first and second axes of the PCA explained $66.24 \%$ of the variance of the data (Table 2). The first principal component explained $37.29 \%$ of the variance, with the MAR $(0.968)$ and Syi $(-0.979)$ being the most significant variables. The second principal component explained $28.95 \%$ of the variance, with the $\mathrm{CV}_{\mathrm{CI}}(0.964)$ and $\mathrm{A}_{2}(0.965)$ being the most significant variables.
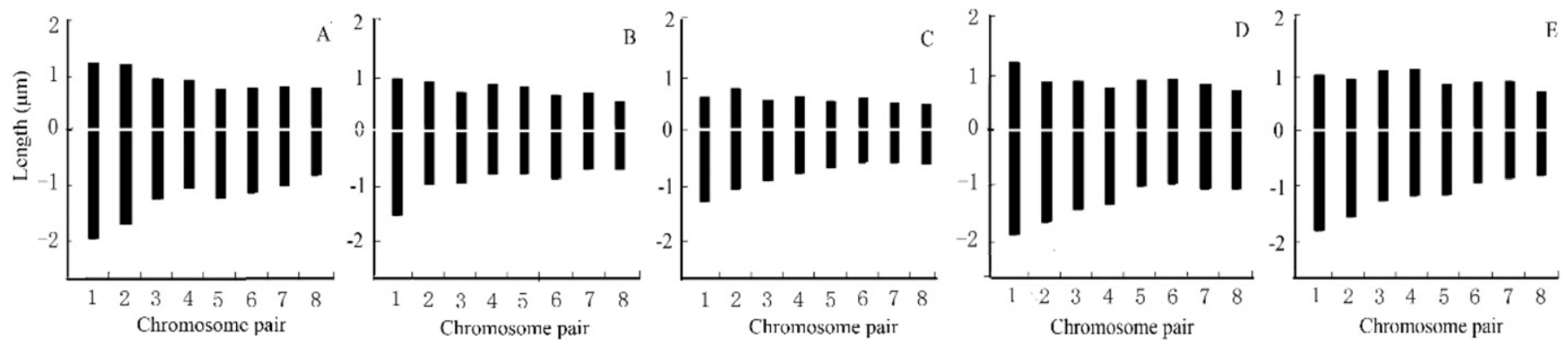

Fig. 3. Ideograms of Prunus armeniaca chromosomes in different ecological groups: (A) DZG 07 accession, (B) DZG 30 accession, (C) DZG 35 accession, (D) CAG 10 accession, and (E) NCG 04 accession. DZG = Dzhungar-Ili ecological group, CAG = Central Asian ecological group, NCG = North China ecological group.

J. Amer. Soc. Hort. ScI. 146(1):68-76. 2021. 


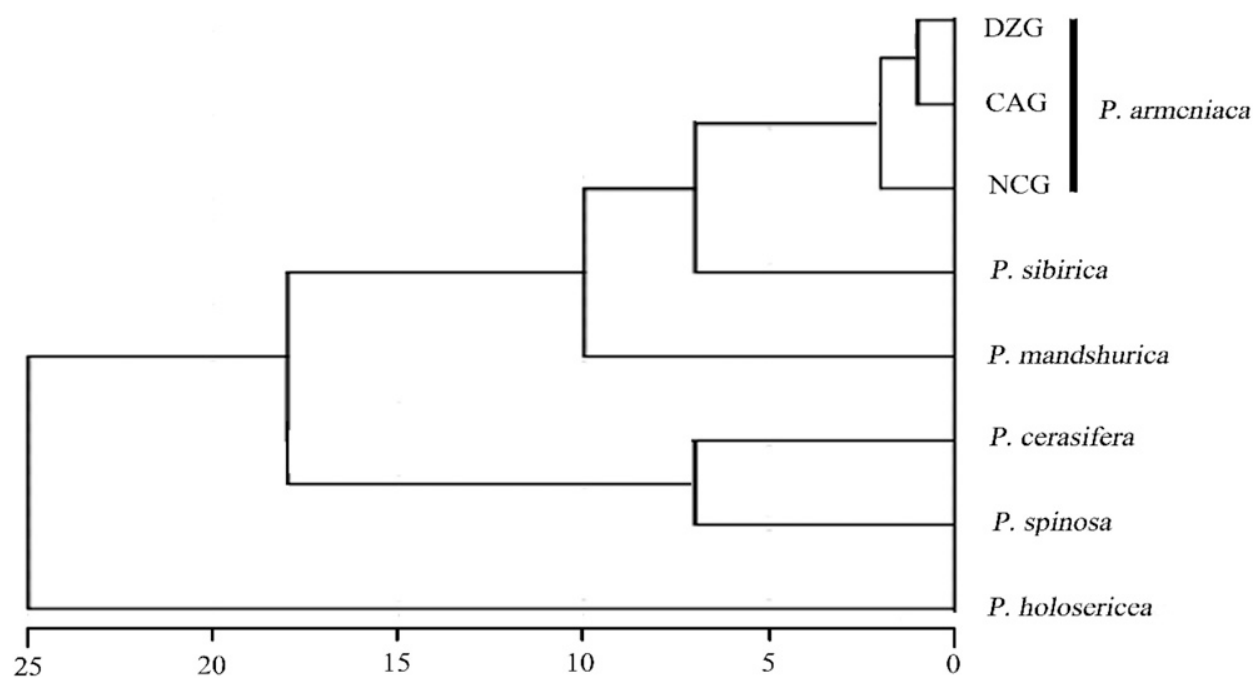

Fig. 4. Depictions of the unweighted pair group method with arithmetic mean clustering analysis of Prunus armeniaca and its related species based on 15 numerical karyological parameters: DZG $=$ Dzhungar-Ili ecological group, $\mathrm{CAG}=$ Central Asian ecological group, $\mathrm{NCG}=$ North China ecological group .

with the results of previous studies of $P$. armeniaca in different regions, although the chromosome number of $P$. armeniaca was the same, there were differences between the karyotype formulas and types. These differences may be due to the genetic diversity of $P$. armeniaca chromosomes and great differences in the climate and environment of the different regions. To better adapt to the environment, the genetic material of regional plants undergoes repatterning and is heterotopic (Chiarini and Bernardello, 2006).

Increasing karyotype asymmetry occurs because of changes in the position of the centromeres toward the terminal or near-terminal areas and differences in the relative size of chromosomes, which makes the karyotype more uneven (Stebbins, 1971; Techio et al., 2010). In addition, chro-

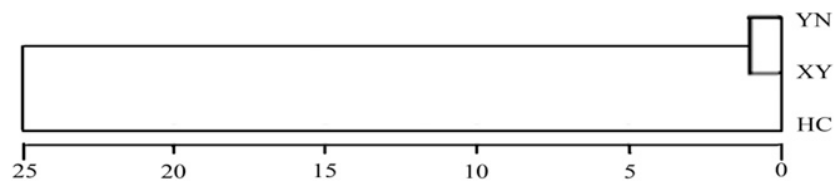

Fig. 5. Depictions of the unweighted pair group method with arithmetic mean clustering analysis of wild Prunus armeniaca based on 15 numerical karyological parameters: $\mathrm{YN}=$ Yining population, $\mathrm{XY}=$ Xinyuan population, $\mathrm{HC}=$ Huocheng population

\section{Discussion}

In this study, the basic chromosome number in the CAG, NCG, and DZG accessions was $x=8$. Kazem et al. (2010) and Lin et al. (1999) confirmed that $P$. armeniaca was $2 n=2 x=16$. Apricot genotypes have a common karyotype pattern, including the presence of $\mathrm{m}$ and $\mathrm{sm}$, and the chromosome length is approximately the same (Lv, 1986). Similarly, the karyotypes analyzed in the present study were widely distributed as $m$ and sm types. The stability of the chromosome number and characteristics may be due to the similarity of the species origin or low selection pressure during the development and cultivation of apricots (Parveen, 2015). However, more detailed genetic and karyological studies are needed to determine variations in chromosome numbers and characteristics among apricot genotypes by the use of more precise techniques to study their cytological aspects.

Variations in chromosome length can be caused by multiple factors, including genotypic and environmental differences (Haque, 1981). The results of this study were different from those of previous studies. For example, Wei and Tang (1996) concluded that the chromosome length of $P$. armeniaca ranged from 1.43 to $4.9 \mu \mathrm{m}$, belonging to the $2 \mathrm{~A}$ or $2 \mathrm{~B}$ type. In our study, the chromosome length of $P$. armeniaca ranged from 0.59 to $2.35 \mu \mathrm{m}$. The karyotypes of the selected accessions were classified mostly as $1 \mathrm{~A}$, with the exception of two accessions from the Xinyuan population in the DZG, which were classified as $2 \mathrm{~A}$. No type $2 \mathrm{~A}$ or $2 \mathrm{~B}$ accession was identified. Compared mosomal asymmetry and size diversity reflect chromosome repatterning during the evolution of the genus (Schubert, 2007), which may have played an important role in the speciation of apricots. We can correctly evaluate the variation in chromosome length through several commonly used indicators of karyotype asymmetry (Chehregani Rad et al., 2015). In this study, the MAR, $\mathrm{M}_{\mathrm{CA}}, \mathrm{A}_{1}$, and A exhibited a consistent trend: the NCG accessions had the greatest values, and the DZG accessions had the lowest values (Table 1). Stebbins (1971) argued that the greater the degree of karyotype symmetry, the smaller the chromosome variation and the lower the degree of evolution. Thus, the more asymmetrical the karyotype of an organism is, the greater its chromosomal variation and evolution. According to our results, the degree of evolution of the DZG accessions was lowest, whereas that of the NCG accessions was the greatest.

Chin et al. (2014) constructed a maximum likelihood tree comprising four-gene concatenated plastid sequences of Prunus and concluded that $P$. armeniaca and $P$. sibirica clustered together, and $P$. cerasifera and $P$. spinosa clustered together. Previous molecular data (Chin et al., 2014) were consistent with the results of this study, indicating that karyotype parameters can be used as an effective means of interspecific identification.

According to Vavilov (1951), China and central Asia were the two main centers of apricot domestication. Most cultivated apricots belong to $P$. armeniaca. Among the four main ecological groups of $P$. armeniaca species, Kostina (1931) argued that DZG accessions are the most primitive and that CAG accessions have the longest cultivation history. The cultivation of the EG accessions has a relatively recent history, being traced back to $\approx 2000$ years ago (Mehlenbacher et al., 1990). $P$. armeniaca originated in northwest China (Ili Valley), subsequently dispersed throughout central Asia, and eventually spread to Europe (Liu et al., 2019). These findings are reasonable from a historical perspective, as there was extensive cultural contact along the Silk Road from 207 BCE to 220 CE (Boulnois, 2004). In central Asia, local cultivars are most likely to have originated from wild apricots, moving southward from the Kazakhstan-China border (Dzhungar-Ili) to Kashmir and westward into the mountains of Afghanistan (Mehlenbacher 
Table 2. Cumulative variance and vector values of the principal component analysis using karyotype parameters of Prunus armeniaca from different ecological groups.

\begin{tabular}{lcc}
\hline & \multicolumn{2}{c}{ Component matrix $^{\mathrm{y}}$} \\
\cline { 2 - 3 } Parameter $^{\mathrm{z}}$ & 1 & 2 \\
\hline $\mathrm{SK}$ & 0.41 & 0.179 \\
$\mathrm{MAR}$ & $\mathbf{0 . 9 6 8}$ & -0.013 \\
$\mathrm{THL}$ & 0.392 & 0.301 \\
$\mathrm{CV}_{\mathrm{CI}}$ & 0.438 & 0.413 \\
$\mathrm{CV}_{\mathrm{CL}}$ & 0.003 & $\mathbf{0 . 9 6 4}$ \\
$\mathrm{M}_{\mathrm{CA}}$ & 0.959 & -0.108 \\
$\mathrm{AsK} \%$ & 0.301 & 0.13 \\
$\mathrm{TF} \%$ & -0.504 & 0.214 \\
$\mathrm{Syi}$ & $-\mathbf{0 . 9 7 9}$ & 0.005 \\
$\mathrm{Rec} \%$ & 0.115 & -0.738 \\
$\mathrm{~A}_{1}$ & 0.937 & -0.125 \\
$\mathrm{~A}_{2}$ & 0.007 & $\mathbf{0 . 9 6 5}$ \\
$\mathrm{A}$ & 0.949 & -0.134 \\
$\mathrm{DI}$ & -0.135 & 0.949 \\
$\mathrm{AI}$ & 0.333 & 0.797 \\
Eigenvalue & 5.59 & 4.34 \\
Contribution rate to variance (\%) & 37.29 & 28.95 \\
Cumulative contribution rate (\%) & 37.29 & 66.24 \\
\hline
\end{tabular}

${ }^{\mathrm{z}} \mathrm{SK}=$ Stebbins karyotype; MAR $=$ mean of long-/short-arm ratio; $\mathrm{THL}=$ total haploid length of chromosome set; $\mathrm{CV}_{\mathrm{CI}}=$ coefficient of variation of the centromeric index; $\mathrm{CV}_{\mathrm{CL}}=$ coefficient of variation of chromosome length; $\mathrm{M}_{\mathrm{CA}}=$ mean centromeric asymmetry; AsK $\%=$ arano index of karyotype asymmetry; $\mathrm{TF} \%=$ total form percentage; Syi $=$ index of karyotype symmetry; Rec $\%=$ index of chromosomal size resemblance; $A_{1}=$ intrachromosomal asymmetry index; $A_{2}=$ inter chromosomal asymmetry index; $\mathrm{A}=$ degree of asymmetry of karyotype; $\mathrm{DI}=$ dispersion index; $\mathrm{AI}=$ karyotype asymmetry index. ${ }^{\mathrm{y}}$ Most significant values are marked in bold.

et al., 1990). Zhebentyayeva et al. (2003) used simple sequence repeat markers to show that cultivated apricots and wild apricots in China were in the same category. He et al. (2007) argued that the genetic diversity of wild apricots in the Ili Valley was the richest, within which the genetic diversity of the Xinyuan population was the greatest. Yuan et al. (2007) used amplified fragment length polymorphism markers to reveal high similarity among different ecological groups of $P$. armeniaca, among which the DZG accessions and CAG accessions were most similar. Li et al. (2020) also concluded that the relationship between the CAG accessions and DZG accessions was close by analyzing the characteristics of apricot pollen grains. Cluster analysis of karyotype parameters revealed that the CAG and DZG accessions belonged to the same category. There is only one mountain between the southern Xinjiang area and Ili area in the northern Tianshan Mountains, and there are several corridors between the northern and southern Tianshan Mountains. Geographically, the cultivated apricot in Xinjiang in the southern Tianshan Mountains (CAG) most likely evolved from the spread of wild apricot genotypes in the Ili Valley (DZG). Karyotypic features also confirmed that the CAG was a very old group in terms of evolutionary history.

\section{Conclusions}

All of the $P$. armeniaca accessions in the different ecological groups studied were diploid $(2 n=2 x=16)$. The THL of the selected accessions ranged from 8.11 to $12.75 \mu \mathrm{m}$, and the chromosomes were small. No satellite chromosomes were detected. During the process of evolution, the chromosomes evolved from being symmetrical to asymmetrical, and the chromosomes of the NCG accessions were more asymmetric than were those of the NCG accessions. The CAG accessions were more closely related to the DZG accessions than to the other accessions. The MAR and Syi were the most valuable karyotype parameters and could be used as powerful tools for identifying apricot genotypes. In this study, karyotype information and relationships of $P$. armeniaca within three ecological groups were provided, establishing a cytological basis for future studies of phylogenetic relationships.

\section{Literature Cited}

Alberto, C.M., A.M. Sanso, and C.C. Xifreda. 2003. Chromosomal studies in species of Salvia (Lamiaceae) from Argentina. Bot. J. Linn. Soc. 141(4):483-490, doi: 10.1046/j.1095-8339.2003.t01-1-00178.x.

Altınordu, F., L. Peruzzi, Y. Yu, and X. He. 2016. A tool for the analysis of chromosomes KaryoType. Taxon 65(3):586-592, doi: $10.12705 / 653$.

Anderson, T.W. 1963. Asymptotic theory for principle component analysis. Ann. Math. Stat. 34(1):122-148, doi: 10.1214/aoms/1177704248.

Arano, H. 1963. Cytological studies in subfamily Carduoideae (Compositae) of Japan IX. The karyotype analysis and phylogenetic considerations on Pertya and Aüzslüæav. Bot. Mag. 76:32-39, doi: 10.15281/jplantres 1887.76.32.

Baltisberger, M. and A. Widmer. 2009. Chromosome numbers and karyotypes within the Ranunculus alpestris-group (Ranunculaceae). Org. Divers. Evol. 9(3):232-243, doi: 10.1016/j.ode.2009.03.003.

Bortiri, E., S.H. Oh, J. Jiang, S. Baggett, A. Granger, C. Weeks, M. Buckingham, D. Potter, and D.E. Parfitt. 2001. Phylogeny and systematics of Prunus (Rosaceae) as determined by sequence analysis of ITS and the chloroplast trnL-trnF spacer DNA. Syst. Bot. 26(4):797-807, doi: 10.1043/0363-6445-26.4.797.

Boulnois, L. (ed.). 2004. Silk Road: Monks, warriors \& merchants on the Silk Road. Norton, New York, NY.

Chehregani Rad, A., H. Salehi, and F. Mohsenzadeh. 2015. Karyomorphological analysis on several diploid populations of Achillea biebersteinii Afan. (Asteraceae) from Iran. Proc. Nat. Acad. Sci., India Sect. Bol. Biol. 87(1):173-180, doi: 10.1007/s40011-0150608-8.

Chen, J.J., X.L. Liu, L.Y. Zhu, and Y. Wang. 2013. Nuclear genome size estimation and karyotype analysis of Lycium species (Solanaceae). Scientia Hort. 151:46-50, doi: 10.1016/j.scienta.2012.12.004.

Chiarini, F. and G. Bernardello. 2006. Karyotype studies in South American species of Solanum subgen. Leptostemonum (Solanaceae). Plant Biol. 8(4):486-493, doi: 10.1055/s-2006-923859.

Chin, S.W., J. Shaw, R. Haberle, J. Wen, and D. Potter. 2014. Diversification of almonds, peaches, plums and cherries - Molecular systematics and biogeographic history of Prunus (Rosaceae). Mol. Phylogenet. Evol. 76:34-48, doi: 10.1016/j.ympev.2014.02.024.

Gecer, M.K., T. Kan, M. Gundogdu, S. Ercisli, G. Ilhan, and H.I. Sagbas. 2020. Physicochemical characteristics of wild and cultivated apricots (Prunus armeniaca L.) from Aras Valley in Turkey. Genet. Resources Crop Evol. 67(4):935-945, doi: 10.1007/s10722-02000893-9.

Ghosh, I., B.K. Bhowmick, and S. Jha. 2018. Cytogenetics of two Indian varieties of Momordica charantia L. (bittergourd). Scientia Hort. 240:333-343, doi: 10.1016/j.scienta.2018.06.027.

Greilhuber, J. and F. Speta. 1976. C-banded karyotypes in the Scilla hohenackeri group, S. persica and Puschkinia (Liliaceae). Plant. Syst. Evol. 126:149-188, doi: 10.1007/BF00981669.

Haque, M.S. 1981. Chromosome numbers in the genus Salvia Linn. P. Indian Acad. Sci. B 47:419-426.

He, T.M., X.S. Chen, Z. Xu, J.S. Gao, P.J. Lin, W. Liu, Q. Liang, and Y. Wu. 2007. Using SSR markers to determine the population genetic 
structure of wild apricot (Prunus armeniaca L.) in the Ily Valley of west China. Genet. Resour. Crop Evol. 54(3):563-572, doi: 10.1007/ s10722-006-0013-5.

Huziwara, Y. 1962. Karyotype analysis in some genera of Compositae. VIII. Further studies on the chromosomes of aster. Amer. J. Bot. 49(2):116-119, doi: 10.2307/2439026.

Jang, T.S., K. Emadzade, J. Parker, E.M. Temsch, A.R. Leitch, F. Speta, and H. Weiss-Schneeweiss. 2013. Chromosomal diversification and karyotype evolution of diploids in the cytologically diverse genus Prospero (Hyacinthaceae). BMC Evol. Biol. 13(1):136, doi: 10.1186/1471-2148-13-136.

Jiang, F., J. Zhang, S. Wang, L. Yang, Y. Luo, S. Gao, M. Zhang, S. Wu, S. Hu, H. Sun, and Y. Wang. 2019. The apricot (Prunus armeniaca L.) genome elucidates Rosaceae evolution and beta-carotenoid synthesis. Hort. Res. 6(1):1-12, doi: 10.1038/s41438-019-0215-6.

Kazem, Y., S. Houshmand, B. Madani, and P. Martínez-Gómez. 2010. Karyotypic studies in Iranian wild almond species. Caryologia 63(2):117-123, doi: 10.1080/00087114.2010.10589716.

Kostina, K.F. 1931. The cultivation of apricots in Fergana Valley. Bull. Appl. Bot. Genet. Plant Breed. 27:153-158.

Lavania, U.C. and S. Srivastava. 1992. A simple parameter of dispersion index that serves as an adjunct to karyotype asymmetry. J. Biosci. 17(2):179-182, doi: 10.1007/BF02703503.

Li, W.W., Y.N. Wang, L.Q. Liu, Y.Y. Niu, S.R. Zhao, S.K. Zhang, Y.T. Wang, and K. Liao. 2020. Pollen morphology of selected apricot (Prunus) taxa. Palynology (4):1-15, doi: 10.1080/01916122.2020. 1737260.

Lin, S.H. 2001. Studies on karyotypes of Armeniaca in China. Adv. Chrom. Sci. 1:248-252.

Lin, S.H., J.Y. Zhang, and C.Q. Fang. 1999. Studies on chromosomes of the wild species and cultivars of Armeniaca. Chin. Soc. Hort. 5:121-125.

Liu, S., C. Amandine, D. Stéphane, T. David, C. Aurélie, E. JeanPhilippe, W.S. Liu, G. Tatiana, and D. Véronique. 2019. The complex evolutionary history of apricots: Species divergence, gene flow and multiple domestication events. Mol. Ecol. Notes 28(24):5299-5314, doi: 10.1111/mec. 15296.

Lv, Z.R. 1986. Karyotype analysis of Prunus sibirica and Prunus armeniaca. J. Hebei Agr. Univ. 2:14-19, doi: 10.16376/j.cnki.bfgs. Martin, E., F. Altınordu, F. Celep, A. Kahraman, and M. Doğan. 2015. Karyomorphological studies in seven taxa of the genus Salvia (Lamiaceae) in Turkey. Caryologia 68(1):13-18, doi: 10.1080/ 00087114.2014.998127.

Mehlenbacher, S., V. Cociu, and L. Hough. 1990. Genetic resources of temperate fruit and nut crops, apricot (Prunus). Acta Hort. 290:65110, doi: 10.17660/ActaHortic.1991.290.3.

Parveen, I. 2015. Cytogenetic, morphological and pollen compatibility studies of some indigenous and exotic cultivars of apricot (Prunus armeniaca L.) grown in Kashmir. PhD Diss., Univ. Agr. Sci. Technol. Kashmi, Jammu and Kashmir, India.

Paszko, A. 2006. A critical review and a new proposal of karyotype asymmetry indices. Plant Syst. Evol. 258:39-48, doi: 10.1007/ s00606-005-0389-2.

Peruzzi, L. and H.E. Eroglu. 2013. Karyotype asymmetry: Again, how to measure and what to measure? Comp. Cytogenet. 7(1):1-9, doi: 10.3897/compcytogen.v7i1.4431.

Rice, A., L. Glick, and S. Abadi. 2015. The Chromosome Counts Database (CCDB) - A community resource of plant chromosome numbers. New Phytol. 206(1):19-26, doi: 10.1111/ nph.13191.
Romero Zarco, C. 1986. A new method for estimating karyotype asymmetry. Taxon 35:526-530, doi: 10.2307/1221906.

Schubert, L. 2007. Chromosome evolution. Curr. Opin. Plant Biol. 10(2):109-115, doi: 10.1016/j.pbi.2007.01.001.

Senica, M., F. Stampar, and M. Mikulic-Petkovsek. 2019. Different extraction processes affect the metabolites in blue honeysuckle (Loniceracaerulea L. subsp. edulis) food products. Turk. J. Agr. For. 43(6):576-585, <http://journals.tubitak.gov.tr/agriculture/>.

Serçe, S., M. Özgen, A.A. Torun, and S. Ercişli. 2010. Chemical composition, antioxidant activities and total phenolic content of Arbutus andrachne L. (Fam. Ericaceae) (the Greek strawberry tree) fruits from Turkey. J. Food Compos. Anal. 23(6):619-623, doi: 10.1016/j.jfca.2009.12.007.

Stace, C.A. 2000. Cytology and cytogenetics as a fundamental taxonomic resource for the $20^{\text {th }}$ and $21^{\text {st }}$ centuries. Taxon 49:451-477, doi: $10.2307 / 1224344$.

Stebbins, G.L. (ed.). 1971. Chromosomal changes, genetic recombination and speciation. Edward Arnold Publ., London, UK.

Sun, Q., K. Liao, and W. Geng. 2015. Karyotype analysis of Prunus domestica L. germplasm resources in Xinjiang. Acta. Bot. Boreal. Occident. Sin. 35(6):1153-1159, doi: 10.7606/j.issn.10004025.2015.06.1153.

Techio, V.H., L.C. Davide, A. Cagliari, S. Barbosa, and A.V. Pereira. 2010. Karyotipic asymmetry of both wild and cultivated species of Pennisetum. Bragantia 69:273-279, doi: 10.1590/S000687052010000200003.

Vavilov, N.I. 1951. The origin, variation, immunity and breeding of cultivated plants. Science 115:433-434.

Wang, R., C.R. Wang, J.S. Pan, and K.W. Zhen. 1992. Studies of keryotype on drupe species in Rosaceae. J. Laiyang Agr. Coll. $9(2): 123-129$.

Watanabe, K., T. Yahara, T. Denda, and K. Kosuge. 1999. Chromosomal evolution in the genus Brachyscome (Asteraceae, Astereae): Statistical tests regarding correlation between changes in karyotype and habit using phylogenetic information. J. Plant Res. 112:145-161, doi: 10.1007/PL00013869.

Wei, W.N. and Q.R. Tang. 1996. Studies on taxonomic relationships of peach, plum, japanese apricot and apricot. J. Hunan Agr. Univ. 22(3):256-260, doi: 10.13331/j.cnki.jhau.

Yuan, Z.H., X.S. Chen, T.M. He, J. Feng, T. Feng, and C. Zhang. 2007. Population genetic structure in apricot (Prunus armeniaca L.) cultivars revealed by fluorescent-AFLP markers in southern Xinjiang, China. J. Genet. Genomics 34(11):1037-1047, doi: 10.1016/S16738527(07)60117-9.

Zhang, J.Y. and Z. Zhang (eds.). 2003. Flora of Chinese fruit trees. China Forestry Press, Beijing, China.

Zhang, Q.P. and W.S. Liu. 2018. Advances of the apricot resources collection, evaluation and germplasm enhancement. Acta Hort. Sin. 45(9):1642-1660, doi: 10.16420/j.issn.0513-353x.20170654.

Zhang, Y., X. Yuan, W. Teng, C. Chen, H. Liu, and J. Wu. 2015. Karyotype diversity analysis and nuclear genome size estimation for Pennisetum Rich. (Poaceae) ornamental grasses reveal genetic relationship and chromosomal evolution. Scientia Hort. 193:22-31, doi: 10.1016/ j.scienta.2015.06.018.

Zhebentyayeva, T.N., G.L. Reighard, V.M. Gorina, and A.G. Abbott. 2003. Simple sequence repeat (SSR) analysis for assessment of genetic variability in apricot germplasm. Theor. Appl. Genet. 106(3):435-444, doi: 10.1007/s00122-002-1069-z. 


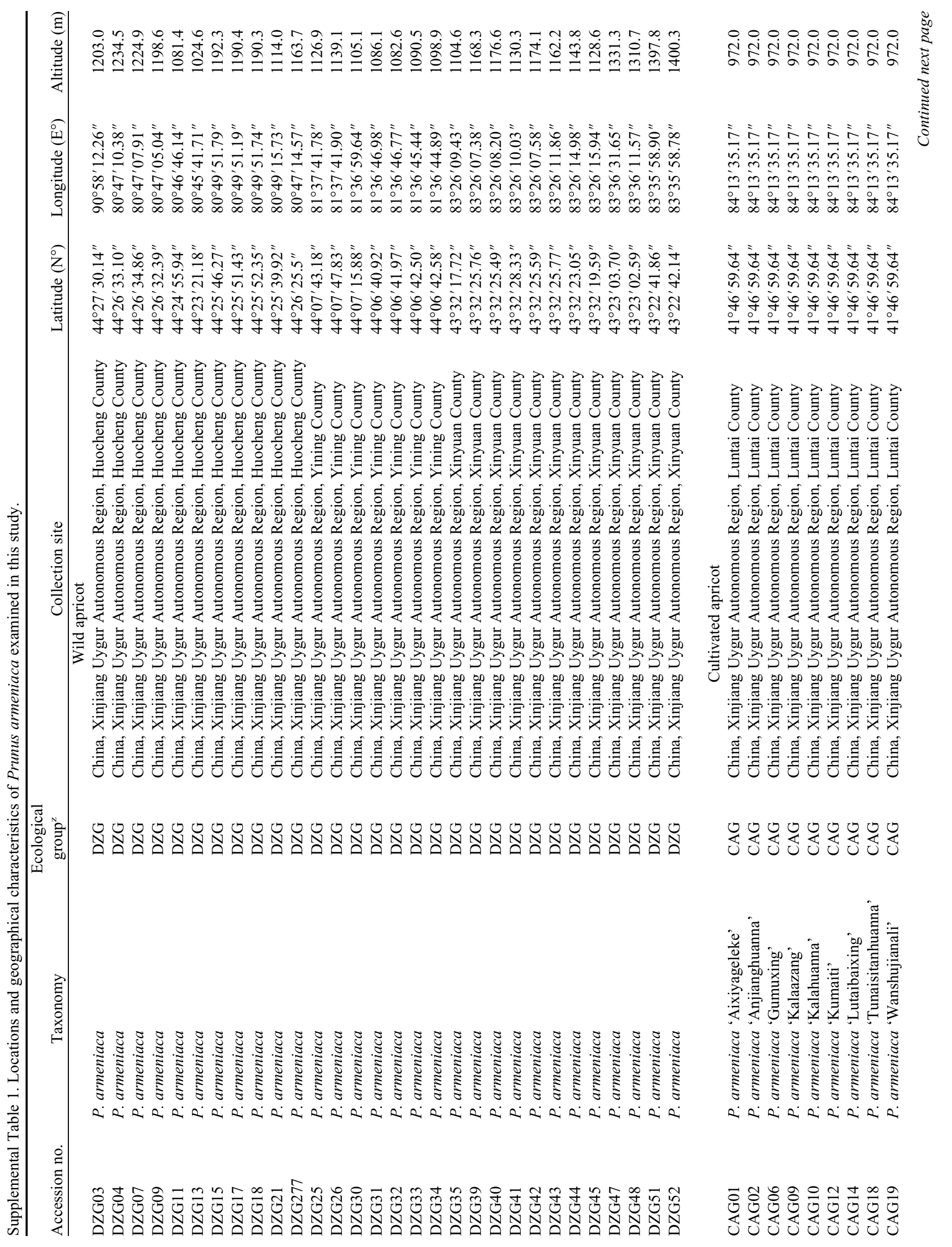




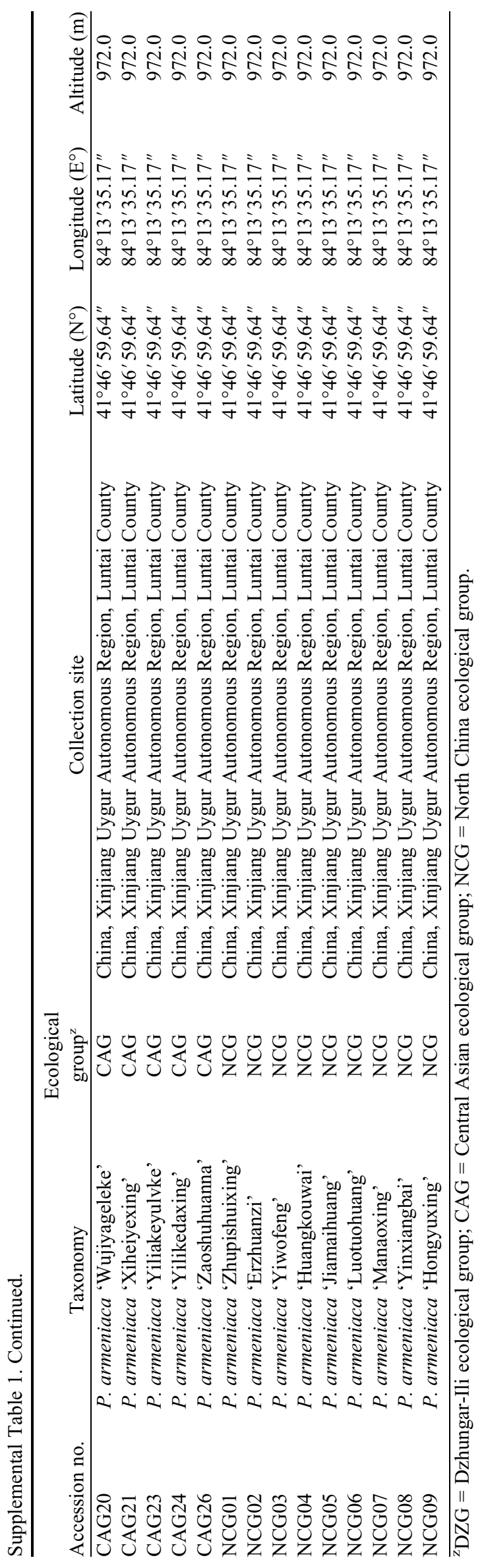

